\title{
Morpho-physiological and biochemical responses of muskmelon genotypes to different degree of water deficit
}

\author{
W.A. ANSARI ${ }^{*, * *}$, N. ATRI ${ }^{* *}$, B. SINGH* ${ }^{*}$ P. KUMAR ${ }^{* * *}$, and S. PANDEY ${ }^{*,+}$ \\ ICAR - Indian Institute of Vegetable Research, P.O.-Jakhani (Shahanshahpur), Varanasi (Uttar Pradesh), 221305, India* \\ Department of Botany, M.M.V, Banaras Hindu University, Varanasi (Uttar Pradesh), 221005, India** \\ ICAR - Central Arid Zone Research Institute, Jodhpur (Rajasthan), 342003, India ${ }^{* * *}$
}

\begin{abstract}
Morpho-physiological and biochemical analyses were carried out in eight diverse indigenous muskmelon (Cucumis melo L.) genotypes exposed to different degrees of water deficit (WD). The ability of genotypes MM-7, and especially MM-6, to counteract better the negative effect of WD was associated with maintaining higher relative water content (RWC), photosynthetic rate, efficiency of PSII, and photosynthetic pigments compare to other genotypes. Furthermore, MM-6 showed a better ability to maintain cellular homeostasis than the others. It was indicated by a stimulated antioxidative defense system, i.e., higher activities of antioxidant enzymes, accumulation of nonenzymatic antioxidants together with lower concentration of reactive oxygen species and malondialdehyde. However, the genotypes MM-2 and MM-5 suffered greatly due to WD and showed reduced RWC, photosynthetic rates, pigment content, and exhibited higher oxidative stress observed as lower antioxidant enzyme activities.
\end{abstract}

Additional key words: antioxidant enzyme; muskmelon; photosynthesis; proline; reactive oxygen species.

\section{Introduction}

Muskmelon (Cucumis melo L.) is an important vegetable that is frequently cultivated in arid and semiarid regions, where water availability is a major limitation (Cabello et al. 2009, Ibrahim 2012). Despite being water a scarce resource in (semi)arid regions, increasing demands of industrial as well as domestic sectors, particularly in developing countries like India, are forcing a decline in water availability for agriculture. Further, the foreseen consequences of change in global climate may worsen the situation in future. This highlights the urgency for developing a new strategy to identify potential genetic resources with specific traits and technological developments that can improve productivity of vegetables under declining natural resources and increasing environmental stresses (Pandey et al. 2016). Drought or water stress represents the most significant environmental constraint, limiting growth and yield efficiency of plants worldwide (Chaves et al. 2002, Adibah and Ainuddin 2011). Plants show either susceptible or tolerant response to water stress that is ascertained by interactive effects of physiological, biochemical, and morphological determinants (Penella et al. 2014).

Plants exposed to WD conditions show reductions in shoot and root biomass, leaf chlorosis and necrosis, while under mild WD, these symptoms are less aparent, but various cellular processes may be altered (Dhillon et al. 2011, Kusvuran 2012). Water stress induces in plants WD and loss of cell turgor, which in turn results in stomatal closure, and ultimately retarded photosynthesis and finally also plant growth (Lawlor 2002). Besides, at the cellular level, WD results in enhanced generation of reactive oxygen species (ROS), such as superoxide radicals $\left(\mathrm{O}_{2}{ }^{-}\right)$,

Received 19 June 2017, accepted 22 November 2017, published as online-first 17 April 2018.

${ }^{+}$Corresponding author; phone: +91-0542-2635247; fax : +91-05443-229007, e-mail: sudhakariivr@gmail.com,

Sudhakar.Pandey@icar.gov.in

Abbreviations: APX - ascorbate peroxidase; Car - caroteinods; CAT - catalase; DM - dry mass; DMRT - Duncan's multiple range tests; DWD - days of water deficit; EL - electrolyte leakage; FM - fresh mass; $\mathrm{F}_{\mathrm{v}} / \mathrm{F}_{\mathrm{m}}$ - maximal quantum yield of PSII photochemistry; GR - glutathione reductase; $g_{\mathrm{s}}$ - stomatal conductance; MDA - malondialdehyde; $P_{\mathrm{N}}$ - net photosynthetic rate; POD - guaiacol peroxidase; RWC - relative water content; SOD - superoxide dismutase; SWC - soil water content; WD - water deficit; WW - well watered. Acknowledgements: The authors acknowledge the generous support of the National Agricultural Innovation Project (NAIP), New Delhi. We thank Dr. A.B. Singh for guidance during the data collection. A Maulana Azad National Fellowship provided to WAA by the University Grant Commission (UGC), New Delhi, India, is fully acknowledged. 
hydrogen peroxide $\left(\mathrm{H}_{2} \mathrm{O}_{2}\right)$, and hydroxyl radicals $\left(\mathrm{OH}^{{ }^{-}}\right)$, which can directly affect membrane lipids and inactivate metabolic enzymes, as well as cause damage to nucleic acids, leading to cell death. The half-life of $\mathrm{H}_{2} \mathrm{O}_{2}$ is comparatively longer than that of other ROS, and the enhanced $\mathrm{H}_{2} \mathrm{O}_{2}$ in plant cells may lead to oxidative stress (Deeba et al. 2012). However, in order to cope with such disorders, plants employ various mechanisms. A complex antioxidant defense system exists against ROS to protect the plant cells (Gill and Tuteja 2010). It includes antioxidant enzymes, such as superoxide dismutase (SOD), catalase (CAT) ascorbate peroxidase (APX), and peroxidase (POD), as well as nonenzymatic antioxidants, such as reduced glutathione, ascorbic acid, $\alpha$-tocopherol, and carotenoids (Kumar et al. 2015a). During the enzymatic detoxifying process, the first enzyme, SOD, dismutates $\mathrm{O}_{2}{ }^{-}$to $\mathrm{H}_{2} \mathrm{O}_{2}$, then CAT and peroxidases scavenge the accumulated $\mathrm{H}_{2} \mathrm{O}_{2}$ to render it to nontoxic concentrations by conversion to $\mathrm{H}_{2} \mathrm{O}$ and $\mathrm{O}_{2}$ (Colla et al. 2013). In addition, the accumulation of compatible solutes (e.g., sugars, proline, glycinebetaine, or potassium) is an important strategy that plants adopt to protect against cellular dehydration by maintaining the osmotic strength of the cytoplasm and thus sustaining plant physiological processes and growth (Lee et al. 2009, Kravić et al. 2013, Penella et al. 2014). Plant responses to WD can be determined by comprehensive analyses of their physiological, biochemical, and molecular traits. Therefore, plant's capacity to withstand WD is of great significance in an ever-changing climate. Once a genotype with high water-use efficiency (WUE) and better yield has been identified, it can be utilized for future breeding programs to develop more efficient varieties (Pandey et al. 2013).

The reactions, as well as a potential to withstand drought environments, depend on the species and

\section{Materials and methods}

Plant materials, experimental conditions and waterstress treatments: Eight diverse indigenous muskmelon genotypes: Arka Jeet (MM-1), IIHR-663 (MM-2), Dharwad Selection 1 (MM-3), Hara Madhu (MM-4), IIHR-595 (MM-5), MJ-7 (MM-6), BS-25 (MM-7), and IIHR-659 (MM-8), were selected for the present study. Genotypes were identified according to preliminary field screening (Pandey et al. 2013). The experiment was conducted at the experimental field of ICAR - Indian Institute of Vegetable Research, Varanasi $\left(25.10^{\circ} \mathrm{N}\right.$, $82.52^{\circ} \mathrm{E}$ and $76.1 \mathrm{~m}$ above mean sea level in the Eastern Indo-Gangetic Plain of India). Plants were grown in 10-L pots $(22 \mathrm{~cm}$ in diameter and $23.8 \mathrm{~cm}$ in height) and the experiment consisted of four sets [i.e., 0 (for control well irrigated), 7, 14, and $21 \mathrm{~d}$ of water deficit, DWD]. Each set was replicated thrice and each genotype included five pots in each set. The soil in the pots was a mixture of sand, loamy clay, and farmyard manure $(1: 2: 1, \mathrm{v} / \mathrm{v})$ with a bulk density of $1.34 \mathrm{~g} \mathrm{~cm}^{-3}$ and $\mathrm{pH} 6.8$. The soil had $0.39 \%$ genotype, duration and level of water loss, age and stage of development, organ, cell type, and type of subcellular compartment (Jaleel et al. 2008). Hence, many reports demonstrate differential responses of species or genotypes to drought stress (Dhillon et al. 2011, Pandey et al. 2013). Although, a number of drought-tolerant genotypes have been identified in many crops (Fleury et al. 2010), limited information is available for muskmelon (Cabello et al. 2009, Kusvuran 2012). In fact, the Indian muskmelon varieties were developed under best agronomic practices, including irrigation, but they have been hardly tested for yield efficiency under drought conditions (Pandey et al. 2008). Like many other vegetables, muskmelon plant is sensitive to water stress probably due to its larger leaf surface which evokes more transpiration, as reported in pepper by Penella et al. (2014). In general, muskmelon growth and productivity are greatly affected by drought stress. For example, the total production of melon in Gansu province (China) declined by $50 \%$ as a result of severe drought (Feng and Wu 2007). Therefore, in the area with decreased water availability, an improvement in crop yield is the main scientific and economic challenge (Penella et al. 2014). The potential of indigenous genetic materials for Indian muskmelon has been revealed in earlier studies for a range of traits (Pandey et al. 2008, 2013, 2016; Ansari et al. 2017). However, detailed study of genotypes required based on various physiological and biochemical parameters to explore the intrinsic potential of selected materials against the specific environmental constraints. In view of this, the present study aimed to elucidate the differencial responses of diverse indigenous genotypes of muskmelon by assessing their intrinsic potential at different physiological and biochemical processes under varying degree of WD.

$(\mathrm{w} / \mathrm{w})$ organic carbon content, $0.30 \%(\mathrm{w} / \mathrm{w})$ total nitrogen content, and $0.51 \mathrm{mg}$ (available phosphorus) $\mathrm{g}^{-1}$, and $0.35 \mathrm{mg}$ (potassium) $\mathrm{g}^{-1}$. During the experiment, mean temperature and relative humidity ranged from 21.4 to $38.2^{\circ} \mathrm{C}$ and $59-89 \%$, respectively. Water (2 L) was applied at 3-d intervals to each pot untill imposition of WD treatment (i.e., $30 \mathrm{~d}$ after seed germination). WD was imposed by withholding water for $0,7,14$, and $21 \mathrm{~d}$ (DWD). The arrangement of experimental pots were random and periodically rotated to minimize the effects of environmental heterogeneity. Plants of muskmelon genotypes were grown under greenhouse conditions and natural light/dark cycle.

Soil moisture was measured according to the formula: soil water content $[\%]=[(\mathrm{FM}-\mathrm{DM}) / \mathrm{DM}] \times 100$, where FM is the fresh mass of the soil portion taken from the pot and DM is the dry mass of the soil portion after drying in a hot air oven at $85^{\circ} \mathrm{C}$ for $4 \mathrm{~d}$ (Cha-um et al. 2013). The fully expanded $6-7^{\text {th }}$ leaf from the tip was harvested on 
$0,7,14$, and $21 \mathrm{DWD}$, frozen immediately in liquid $\mathrm{N}_{2}$ for the biochemical measurements, and kept at $-80^{\circ} \mathrm{C}$ until used, while the other observation were carried out on fresh leaves. Three samples were taken from each genotype in each replication.

Root length, dry-to-fresh mass ratio of root, shoot and leaf: Plants were removed from the soil with intact roots to measure root length on $0,7,14$, and 21 DWD. The root, shoot, and leaf parts were carefully separated and their FM was recorded. Respective plant parts were dried in an oven at $80^{\circ} \mathrm{C}$ for $48 \mathrm{~h}$ and DM was recorded. The ratio of dryto-fresh mass (DM/FM) was calculated in percentage according to the formula given by Kausar et al. (2012) with minor modifications:

$$
\begin{aligned}
& \mathrm{RDM} / \mathrm{RFM}[\%]=(\mathrm{RDM} / \mathrm{RFM}) \times 100 \\
& \mathrm{SDM} / \mathrm{SFM}[\%]=(\mathrm{SDM} / \mathrm{SFM}) \times 100 \\
& \mathrm{LDM} / \mathrm{LFM}[\%]=(\mathrm{LDM} / \mathrm{LFM}) \times 100
\end{aligned}
$$

where RDM is root dry mass, RFM is root fresh mass, SDM is shoot dry mass, SFM is shoot fresh mass, LDM is leaf dry mass and LFM is leaf fresh mass.

Relative water content (RWC) and electrolyte leakage (EL): At 0, 7, 14, and 21 DWD, the RWC and EL of leaf tissues were measured as described by Khare et al. (2010). To determine the RWC, 12 leaf discs were weighed (FM). The same tissues were rehydrated in water for $6 \mathrm{~h}$ until fully turgid, surface-dried, and reweighed [turgid mass (TM)] followed by oven-drying at $80^{\circ} \mathrm{C}$ for $24 \mathrm{~h}$, and reweighing (DM). The RWC was calculated by the following equation: RWC $[\%]=[(\mathrm{FM}-\mathrm{DM}) /(\mathrm{TM}-\mathrm{DM})]$ $\times 100$. EL was measured using a conductivity meter (CM-180, Elico, India): 10 leaf discs were placed in $25 \mathrm{ml}$ of Milli Q water and their conductivity was measured after $4 \mathrm{~h}$ at room temperature $(a)$ and then after autoclaving at $121^{\circ} \mathrm{C}$ for $30 \mathrm{~min}(b)$. The EL was calculated as: EL [\%] = $a / b \times(100)$.

Net photosynthetic rate, stomatal conductance, and chlorophyll (Chl) fluorescence: Net photosynthetic rate $\left(P_{\mathrm{N}}\right)$ and stomatal conductance $\left(g_{\mathrm{s}}\right)$ were measured after $0,7,14$, and 21 DWD in three fully expanded intermediate leaves in each replications and each genotype with a portable photosynthetic system (LI 6400, LICOR, Lincoln, NE, USA) from 11.00 to $13.00 \mathrm{~h}$ using a $250-\mathrm{cm}^{3}$ closedcircuit cuvette (Cha-um et al. 2007). These measurements were completed with the following specifications: ambient $\mathrm{CO}_{2}$ concentration of $350 \mathrm{mmol} \mathrm{mol}{ }^{-1}$, cuvette air temperature set to $32^{\circ} \mathrm{C}$ before and after the respective treatments, and to $28^{\circ} \mathrm{C}$ during the relative treatment, relative humidity ranged between $65-70 \%$. PAR at leaf surface was maximum up to $1,060 \mu \operatorname{mol}\left(\right.$ photon) $\mathrm{m}^{-2} \mathrm{~s}^{-1}$. Photosynthetic efficiency was determined after $0,7,14$, and 21 DWD in three fully expanded intermediate leaves using a portable Handy Plant Efficiency Analyzer (Hansatech Instruments, King's Lynn, Norfolk, UK). The leaves were dark-adapted for 30 min using leaf clips on the adaxial side. Red light was used to irradiate the leaf surface; the fluorescence signal was collected at excitation irradiance, set at 3,000 $\mu \mathrm{mol}$ (photon) $\mathrm{m}^{-2} \mathrm{~s}^{-1}$ from the same surface. Minimum $\left(\mathrm{F}_{0}\right)$ and maximum $\left(\mathrm{F}_{\mathrm{m}}\right)$ Chl fluorescence of the dark-adapted leaf was recorded and maximum quantum efficiency of PSII was calculated according to: $\mathrm{F}_{\mathrm{v}} / \mathrm{F}_{\mathrm{m}}=\left(\mathrm{F}_{\mathrm{m}}-\mathrm{F}_{0}\right) / \mathrm{F}_{\mathrm{m}}$ (Maxwell and Johnson 2000).

Photosynthetic pigments: For $\mathrm{Chl}$ and carotenoid (Car) content estimations, leaf samples $(300 \mathrm{mg})$ were crushed in $80 \%$ chilled acetone using a mortar and pestle. Absorbance of supernatant was read ( $U V$-vis 1601 Shimadzu, Japan) at 663, 645, and $470 \mathrm{~nm}$ and calculated according to Lichtenthaler and Buschmann (2001). Chl and Car contents $\left[\mathrm{mg} \mathrm{g}^{-1}(\mathrm{DM})\right]$ were calculated using the formula: Chl $a=\left[\left(12.7 \times \mathrm{A}_{663}\right)-\left(2.69 \times \mathrm{A}_{645}\right)\right]$; $\mathrm{Chl} b=$ $\left[\left(22.9 \times \mathrm{A}_{645}\right)-\left(4.68 \times \mathrm{A}_{663}\right)\right] ; \mathrm{Car}=\left[\left\{\left(1,000 \times \mathrm{A}_{470}\right)-\right.\right.$ $(3.27 \times \mathrm{Chl} a+\mathrm{Chl} b)\} / 227]$.

Estimation of $\mathrm{H}_{2} \mathrm{O}_{2}$, lipid peroxidation and proline: The $\mathrm{H}_{2} \mathrm{O}_{2}$ contents were determined according to Jana and Choudhuri (1981). Leaf samples (200 mg) were crushed in $5 \mathrm{ml}$ of $50 \mathrm{mM}$ sodium phosphate buffer $(\mathrm{pH} 6.5)$. Supernatant $(3 \mathrm{ml})$ was mixed with $1 \mathrm{ml}$ of $0.1 \%(\mathrm{w} / \mathrm{v})$ titanium sulfate in $20 \%(\mathrm{v} / \mathrm{v}) \mathrm{H}_{2} \mathrm{SO}_{4}$ and centrifuged at $6,000 \times g$ for $15 \mathrm{~min}$, absorbance was recorded at $410 \mathrm{~nm}$ (UV-vis 1601 Shimadzu, Japan).

Lipid peroxidation was measured as malondialdehyde content (MDA) by thiobarbituric acid reaction according to the method of Heath and Packer (1968). Approximately $400 \mathrm{mg}$ of leaf sample was crushed in $4 \mathrm{ml}$ of $0.1 \%(\mathrm{v} / \mathrm{v})$ trichloroacetic acid mixed with $0.5 \%(\mathrm{v} / \mathrm{v})$ butylated hydroxytoluene and $1 \%(\mathrm{w} / \mathrm{v})$ polyvinylpyrrolidone (PVP). The supernatant $(2.5 \mathrm{ml})$ was mixed with $0.5 \%(\mathrm{v} / \mathrm{v})$ and $20 \%$ thiobarbituric acid and trichloroacetic acid, respectively, and boiled for $30 \mathrm{~min}$, absorbance of the supernatant at $532 \mathrm{~nm}$ was noted and correction for nonspecific turbidity was performed by subtracting the supernatant's absorbance at $600 \mathrm{~nm}$ (UV-vis 1601 Shimadzu, Japan).

To estimate the proline content, leaf tissues $(200 \mathrm{mg})$ were homogenized in $3 \%(\mathrm{v} / \mathrm{v})$ sulfosalicylic acid. After centrifugation $(13,000 \times g$ for $10 \mathrm{~min}), 0.5 \mathrm{ml}$ of the supernatant was incubated at $100^{\circ} \mathrm{C}$ for $60 \mathrm{~min}$ with $0.5 \mathrm{ml}$ glacial acetic acid and $0.5 \mathrm{ml}$ freshly prepared ninhydrin reagent. Toluene $(1 \mathrm{ml})$ was added to the mixture and the absorbance was recorded at $520 \mathrm{~nm}$ (Bates et al. 1973) (UV-vis 1601 Shimadzu, Japan).

Determination of antioxidant enzyme activity and protein contents: Catalase (CAT; EC 1.11.1.6) activity was estimated according to Rai et al. (2012). Fresh leaf sample $(200 \mathrm{mg})$ was homogenized in $5 \mathrm{ml}$ of $50 \mathrm{mM}$ Tris$\mathrm{NaOH}$ buffer ( $\mathrm{pH} 8.0)$ containing $0.5 \mathrm{mM}$ EDTA, $2 \%$ PVP, and $0.5 \%(\mathrm{v} / \mathrm{v})$ Triton $X-100$. The $1.5-\mathrm{ml}$ assay

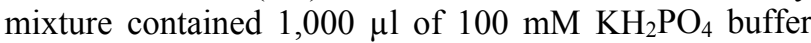

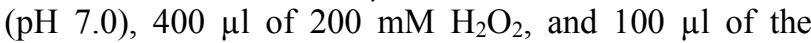


enzyme extract. The degradation of $\mathrm{H}_{2} \mathrm{O}_{2}$ was recorded at $240 \mathrm{~nm}$, CAT activity was expressed as $\mu \mathrm{mol}\left(\mathrm{H}_{2} \mathrm{O}_{2}\right.$ oxidized) $\mathrm{min}^{-1} \mathrm{mg}^{-1}$ (protein). The superoxide dismutase (SOD; EC 1.15.1.1) activity was assayed according to the method of Shah et al. (2001). Fresh leaf sample (200 mg) was homogenized in $5 \mathrm{ml}$ of $100 \mathrm{mM}$ potassium phosphate buffer $(\mathrm{pH} 7.5)$. Homogenate was centrifuged at 22,000 $\times g$ for $10 \mathrm{~min}$ at $4^{\circ} \mathrm{C}$ and SOD activity was assayed in the supernatant. The assay mixture contained $50 \mathrm{mM}$ sodium carbonate-bicarbonate buffer $(\mathrm{pH} 9.8)$ containing $0.1 \mathrm{mM}$ EDTA, $0.6 \mathrm{mM}$ epinephrine, and enzyme extract in a final volume of $3 \mathrm{ml}$. Adrenochrome formation was recorded at $470 \mathrm{~nm}$ (UV-vis 1601 Shimadzu, Japan). One unit of SOD activity is equal to the amount of enzyme required to cause $50 \%$ inhibition of epinephrine oxidation and is expressed as $\mathrm{U} \mathrm{mg}^{-1}$ (protein). Ascorbate peroxidase (APX; EC 1.11.1.11) activity was determined according to the method of Nakano and Asada (1981). Fresh leaf sample $(200 \mathrm{mg}$ ) was homogenized in $5 \mathrm{ml}$ of $50 \mathrm{mM}$ potassium phosphate buffer ( $\mathrm{pH} 7.8$ ) containing $1.0 \mathrm{mM}$ EDTA, 1\% PVP, $1.0 \mathrm{mM}$ ascorbic acid, and $1.0 \mathrm{mM}$ phenylmethylsulfonyl fluoride. The reaction mixture in a final volume of $3 \mathrm{ml}$ contained $50 \mathrm{mM}$ potassium phosphate buffer (pH 7.0), $0.2 \mathrm{mM}$ EDTA, $0.5 \mathrm{mM}$ ascorbic acid, $0.2 \mathrm{mM}$ $\mathrm{H}_{2} \mathrm{O}_{2}$, and the extracted enzyme, and the absorbance was recorded at $290 \mathrm{~nm}$ (UV-vis 1601 Shimadzu, Japan). The specific activity of APX was expressed as $\mu \mathrm{mol}$ (ascorbate oxidized) $\mathrm{min}^{-1} \mathrm{mg}^{-1}$ (protein). Glutathione reductase (GR; EC 1.6.4.2) activity was assayed as per the mechanism described by Sánchez-Rodríguez et al. (2010). Fresh leaf sample $(200 \mathrm{mg})$ was crushed in $5 \mathrm{ml}$ of $0.1 \mathrm{M}$ Tris- $\mathrm{HCl}$ buffer ( $\mathrm{pH}$ 7.8). The reaction mixture in a final volume of $2 \mathrm{ml}$ contained $100 \mathrm{mM}$ Tris- $\mathrm{HCl}$ buffer ( $\mathrm{pH} 7.8), 0.2 \mathrm{mM}$

\section{Results}

The morphological, physiological and biochemical analyses revealed that there were significant variations among the genotypes in all the parameters analyzed at each point of WD treatments even before the imposition of WD treatments or under well watered (WW) conditions, except for proline and Car contents at WW conditions (Tables 1-5, Fig. $1 A-E$ ). The soil water content (SWC) of the pot was $45,27,13$, and $8.5 \%$, respectively, at $0,7,14$, and 21 DWD (the value presents average of all pots in each set).

Morphological parameters: As presented in Table 1, root length increased in all the genotypes as WD advanced. With exception of MM-2, statistically similar root length was observed in all the genotypes analyzed at WW conditions. In response to stage of WD, the maximum root length was recorded in MM-1 followed by MM- 6 within each point of WD. The DM/FM ratio of shoots, roots, and leaves were significantly affected by DWD, with maximum at 21 DWD in MM-5 for shoots, in MM-5 and MM-8 for roots, and in MM-2, MM-4, MM-5 for leaves, respectively. Under similar conditions, the minimum value
$\mathrm{NADPH}, 0.5 \mathrm{mM}$ oxidized glutathione, $3 \mathrm{mM} \mathrm{MgCl}_{2}$, and $200 \mu 1$ of the enzyme extract. The assay was initiated by addition of NADPH at ambient temperature and the decrease in absorbance was recorded at $340 \mathrm{~nm}$ ( $U V$-vis 1601 Shimadzu, Japan) and the specific activity of GR was expressed as $\mu \mathrm{mol}\left(\mathrm{NADPH}\right.$ oxidized) $\mathrm{min}^{-1} \mathrm{mg}^{-1}$ (protein). Guaiacol peroxidase (POD; EC 1.11.1.7) activity was assayed according to Shah et al. (2001). Leaf sample (200 $\mathrm{mg}$ ) was homogenized in $5 \mathrm{ml}$ of $60 \mathrm{mM}$ sodium phosphate buffer ( $\mathrm{pH} 7.0$ ), centrifuged, and the supernatant was used for enzyme assay. The reaction mixture consisted of $100 \mathrm{mM}$ potassium phosphate buffer ( $\mathrm{pH} 6.5)$, $15 \mathrm{mM}$ guaiacol, $0.05 \%$ (v/v) $\mathrm{H}_{2} \mathrm{O}_{2}$, and $60 \mu \mathrm{l}$ enzyme extract. The reaction was initiated by adding $\mathrm{H}_{2} \mathrm{O}_{2}$ and the oxidation of guaiacol was determined by the increase in absorbance at $470 \mathrm{~nm}$, the specific activity of POD was expressed $\mu \mathrm{mol}\left(\mathrm{H}_{2} \mathrm{O}_{2}\right.$ reduced) $\mathrm{min}^{-1} \mathrm{mg}^{-1}$ (protein). All the absorbance were measured using spectrophotometer (UV-vis 1601 Shimadzu, Japan). Lowry's method was followed to measure the protein in each enzyme preparation, using bovine serum albumin (BSA) as the standard (Lowry et al. 1951).

Statistical analysis: All statistical analyses were performed using the statistical package SPSS (SPSS Inc., Version 16.0). Three samples from each replication were taken and mean value of each replication was used for statistical analysis and significance difference was assessed by one-way analysis of variance (ANOVA), and further analyzed by Duncan's multiple range tests. The significance level for post hoc test was set at $5 \%$ and $P<0.05$ was treated as significant.

was observed in MM-6 for shoots, in MM-6 and MM-7 for roots, and in MM-1, MM-3, MM-6, MM-7, and MM-8 for leaves, respectively (Tables 1 and 2).

Physiological parameters: Significant variation among the genotypes was observed with respect to all the physiological parameters, except $\mathrm{F}_{\mathrm{v}} / \mathrm{F}_{\mathrm{m}}$ at $\mathrm{WW}$ conditions. The RWC progressively decreased in all genotypes as the level of WD advanced (Table 2). Genotype MM-6 and MM-7 exhibited higher RWC at each WD level. At 7 DWD, except MM-6 and MM-7, all genotypes showed insignificant differences in their RWC. However, at $14 \mathrm{DWD}$, the highest RWC was found in MM-6 and MM-7, while MM-5 showed the lowest RWC. At 21 DWD, genotypes MM-2, MM-3, MM-8, and MM-4, MM-5 were grouped together with lower RWC (Table 2). Compared to the others, a significant and consistently the highest $P_{\mathrm{N}}$ was recorded for MM-6, and the lowest for MM-5 at each WD level. The $F_{v} / F_{m}$ was the highest in MM-6 until 14 DWD, however, at 21 DWD, it was the highest in MM-1, MM-7, and MM-6. The lowest $F_{\mathrm{v}} / \mathrm{F}_{\mathrm{m}}$ was recorded in MM-5 at 0, 7, 
14, and 21 DWD (Table 3). The $g_{\text {s }}$ was reduced with respect to the increasing WD (from 7 to 21 DWD) in each genotype, but genotype MM-7 mainatined higher $g_{\mathrm{s}}$ at each
WD level compare to other genotypes, and especially MM-5, which con-sistently showed the lowest $g_{\mathrm{s}}$ at each WD level (Table 3).

Table 1. Effect of increasing water deficit on root length, root and shoot dry-to-fresh mass ratio in muskmelon. Data are means \pm SE of three replication. Means followed by the same letter within a column are not significantly different $(P>0.05)$ according to Duncan's multiple range tests; ${ }^{\#}$ - well-watered plants. 7, 14, and $21 \mathrm{~d}$ represents water-deficit treatment for respective day.

\begin{tabular}{lllllllllllll}
\hline \multirow{2}{*}{ Genotype } & \multicolumn{3}{c}{ Root length [cm] } & \multicolumn{4}{c}{ Root dry-to-fresh mass ratio [\%] } & \multicolumn{3}{c}{ Shoot dry-to-fresh mass ratio [\%] } \\
& $0 \mathrm{~d}^{\#}$ & $7 \mathrm{~d}$ & $14 \mathrm{~d}$ & $21 \mathrm{~d}$ & $0 \mathrm{~d}^{\#}$ & $7 \mathrm{~d}$ & $14 \mathrm{~d}$ & $21 \mathrm{~d}$ & $0 \mathrm{~d}^{\#}$ & $7 \mathrm{~d}$ & $14 \mathrm{~d}$ & $21 \mathrm{~d}$ \\
\hline MM-1 & $29.7^{\mathrm{a}}$ & $33.1^{\mathrm{ab}}$ & $43.3^{\mathrm{a}}$ & $52.2^{\mathrm{a}}$ & $16.5^{\mathrm{bc}}$ & $22.1^{\mathrm{cd}}$ & $30.8^{\mathrm{c}}$ & $37.8^{\mathrm{c}}$ & $14.8^{\mathrm{a}}$ & $18.7^{\mathrm{b}}$ & $25.5^{\mathrm{bc}}$ & $34.2^{\mathrm{c}}$ \\
MM-2 & $16.5^{\mathrm{b}}$ & $17.1^{\mathrm{c}}$ & $18.3^{\mathrm{d}}$ & $20.4^{\mathrm{d}}$ & $15.1^{\mathrm{c}}$ & $24.0^{\mathrm{bc}}$ & $37.3^{\mathrm{bc}}$ & $47.6^{\mathrm{bc}}$ & $10.0^{\mathrm{b}}$ & $20.1^{\mathrm{b}}$ & $32.0^{\mathrm{b}}$ & $48.0^{\mathrm{b}}$ \\
MM-3 & $25.4^{\mathrm{a}}$ & $27.9^{\mathrm{ab}}$ & $33.3^{\mathrm{bc}}$ & $39.7^{\mathrm{bc}}$ & $15.1^{\mathrm{c}}$ & $21.6^{\mathrm{cd}}$ & $32.1^{\mathrm{c}}$ & $41.8^{\mathrm{bc}}$ & $11.2^{\mathrm{ab}}$ & $18.2^{\mathrm{b}}$ & $26.2^{\mathrm{bc}}$ & $34.3^{\mathrm{c}}$ \\
MM-4 & $32.0^{\mathrm{a}}$ & $34.7^{\mathrm{a}}$ & $40.3^{\mathrm{ab}}$ & $43.2^{\mathrm{b}}$ & $17.8^{\mathrm{ab}}$ & $25.0^{\mathrm{bc}}$ & $35.3^{\mathrm{bc}}$ & $47.3^{\mathrm{bc}}$ & $10.6^{\mathrm{ab}}$ & $18.3^{\mathrm{b}}$ & $25.6^{\mathrm{bc}}$ & $35.6^{\mathrm{c}}$ \\
MM-5 & $27.3^{\mathrm{a}}$ & $28.2^{\mathrm{ab}}$ & $29.9^{\mathrm{c}}$ & $31.0^{\mathrm{c}}$ & $18.8^{\mathrm{a}}$ & $31.4^{\mathrm{a}}$ & $51.4^{\mathrm{a}}$ & $63.6^{\mathrm{a}}$ & $13.2^{\mathrm{ab}}$ & $26.3^{\mathrm{a}}$ & $39.5^{\mathrm{a}}$ & $58.3^{\mathrm{a}}$ \\
MM-6 & $25.7^{\mathrm{a}}$ & $29.2^{\mathrm{ab}}$ & $38.8^{\mathrm{abc}}$ & $52.5^{\mathrm{a}}$ & $15.0^{\mathrm{c}}$ & $17.7^{\mathrm{d}}$ & $21.6^{\mathrm{d}}$ & $24.6^{\mathrm{d}}$ & $9.6^{\mathrm{b}}$ & $11.6^{\mathrm{c}}$ & $16.6^{\mathrm{d}}$ & $23.1^{\mathrm{d}}$ \\
MM-7 & $24.6^{\mathrm{a}}$ & $27.1^{\mathrm{b}}$ & $35.4^{\mathrm{ab}}$ & $41.1^{\mathrm{b}}$ & $17.4^{\mathrm{ab}}$ & $23.2^{\mathrm{bc}}$ & $33.8^{\mathrm{bc}}$ & $44.9^{\mathrm{bc}}$ & $12.5^{\mathrm{ab}}$ & $16.3^{\mathrm{b}}$ & $21.0^{\mathrm{cd}}$ & $29.4^{\mathrm{cd}}$ \\
MM-8 & $28.8^{\mathrm{a}}$ & $30.2^{\mathrm{ab}}$ & $32.6^{\mathrm{bc}}$ & $36.2^{\mathrm{bc}}$ & $18.7^{\mathrm{a}}$ & $27.7^{\mathrm{ab}}$ & $41.5^{\mathrm{b}}$ & $53.9^{\mathrm{ab}}$ & $8.8^{\mathrm{b}}$ & $18.7^{\mathrm{b}}$ & $28.9^{\mathrm{b}}$ & $43.8^{\mathrm{b}}$ \\
\hline
\end{tabular}

Table 2. Effect of increasing water deficit on leaf dry-to-fresh mass ratio and relative water content in muskmelon. Data are means \pm SE of three replication. Means followed by the same letter within a column are not significantly different $(P>0.05)$ according to Duncan's multiple range tests; ${ }^{*}$ - well-watered plants. 7, 14, and $21 \mathrm{~d}$ represents water-deficit treatment for respective day.

\begin{tabular}{lllllllll}
\hline \multirow{2}{*}{ Genotype } & \multicolumn{3}{c}{ Leaf dry-to-fresh mass ratio [\%] } & \multicolumn{3}{c}{ Relative water content [\%] } \\
& $0 \mathrm{~d}^{\#}$ & $7 \mathrm{~d}$ & $14 \mathrm{~d}$ & $21 \mathrm{~d}$ & $0 \mathrm{~d}^{\#}$ & $7 \mathrm{~d}$ & $14 \mathrm{~d}$ & $21 \mathrm{~d}$ \\
\hline MM-1 & $27.3^{\mathrm{ab}}$ & $33.2^{\mathrm{a}}$ & $36.2^{\mathrm{a}}$ & $41.4^{\mathrm{bcd}}$ & $64.7^{\mathrm{c}}$ & $56.4^{\mathrm{c}}$ & $46.1^{\mathrm{b}}$ & $41.2^{\mathrm{b}}$ \\
MM-2 & $26.8^{\mathrm{ab}}$ & $34.2^{\mathrm{a}}$ & $38.3^{\mathrm{a}}$ & $44.4^{\mathrm{ab}}$ & $76.7^{\mathrm{a}}$ & $59.0^{\mathrm{bc}}$ & $43.2^{\mathrm{b}}$ & $36.9^{\mathrm{bc}}$ \\
MM-3 & $28.8^{\mathrm{ab}}$ & $35.8^{\mathrm{a}}$ & $37.6^{\mathrm{a}}$ & $41.5^{\mathrm{bcd}}$ & $64.5^{\mathrm{c}}$ & $54.5^{\mathrm{c}}$ & $42.7^{\mathrm{b}}$ & $35.3^{\mathrm{bc}}$ \\
MM-4 & $18.8^{\mathrm{d}}$ & $34.2^{\mathrm{a}}$ & $38.8^{\mathrm{a}}$ & $43.4^{\mathrm{abc}}$ & $66.2^{\mathrm{bc}}$ & $57.2^{\mathrm{c}}$ & $46.0^{\mathrm{b}}$ & $34.8^{\mathrm{c}}$ \\
MM-5 & $31.8^{\mathrm{a}}$ & $36.3^{\mathrm{a}}$ & $39.2^{\mathrm{a}}$ & $48.3^{\mathrm{a}}$ & $74.0^{\mathrm{ab}}$ & $55.9^{\mathrm{c}}$ & $38.5^{\mathrm{c}}$ & $32.0^{\mathrm{c}}$ \\
MM-6 & $23.3^{\mathrm{cd}}$ & $24.8^{\mathrm{b}}$ & $31.4^{\mathrm{a}}$ & $37.2^{\mathrm{d}}$ & $74.1^{\mathrm{ab}}$ & $69.9^{\mathrm{a}}$ & $59.7^{\mathrm{a}}$ & $58.0^{\mathrm{a}}$ \\
MM-7 & $24.1^{\mathrm{bc}}$ & $32.9^{\mathrm{a}}$ & $36.7^{\mathrm{a}}$ & $39.3^{\mathrm{cd}}$ & $74.8^{\mathrm{a}}$ & $66.7^{\mathrm{ab}}$ & $57.9^{\mathrm{a}}$ & $54.7^{\mathrm{a}}$ \\
MM-8 & $31.7^{\mathrm{a}}$ & $35.8^{\mathrm{a}}$ & $38.2^{\mathrm{a}}$ & $42.2^{\mathrm{bcd}}$ & $72.0^{\mathrm{abc}}$ & $58.1^{\mathrm{c}}$ & $43.3^{\mathrm{b}}$ & $36.7^{\mathrm{bc}}$ \\
\hline
\end{tabular}

Table 3. Effect of increasing water deficit on net photosynthetic rate, stomatal conductance, and $\mathrm{F}_{\mathrm{v}} / \mathrm{F}_{\mathrm{m}}$ in muskmelon. Data are means $\pm \mathrm{SE}$ of three replication. Means followed by the same letter within a column are not significantly different $(P>0.05)$ according to Duncan's multiple range tests; \# - well-watered plants; $\mathrm{F}_{\mathrm{v}} / \mathrm{F}_{\mathrm{m}}$ - maximal quantum yield of PSII photochemistry. 7, 14, and $21 \mathrm{~d}$ represents water-deficit treatment for respective day.

\begin{tabular}{|c|c|c|c|c|c|c|c|c|c|c|c|c|}
\hline \multirow[t]{2}{*}{ Genotype } & \multicolumn{4}{|c|}{$\begin{array}{l}\text { Net photosynthetic rate } \\
{\left[\mu \mathrm{mol} \mathrm{m} \mathrm{m}^{-2} \mathrm{~s}^{-1}\right]}\end{array}$} & \multicolumn{3}{|c|}{$\begin{array}{l}\text { Stomatal conductance } \\
{\left[\mathrm{mmol}\left(\mathrm{H}_{2} \mathrm{O}\right) \mathrm{m}^{-2} \mathrm{~s}^{-1}\right]}\end{array}$} & \multirow[b]{2}{*}{$21 \mathrm{~d}$} & \multicolumn{2}{|l|}{$\mathrm{F}_{\mathrm{v}} / \mathrm{F}_{\mathrm{m}}$} & \multirow[b]{2}{*}{$14 \mathrm{~d}$} & \multirow[b]{2}{*}{$21 \mathrm{~d}$} \\
\hline & $0 \mathrm{~d}^{\#}$ & $7 \mathrm{~d}$ & $14 \mathrm{~d}$ & $21 \mathrm{~d}$ & $0 \mathrm{~d}^{\#}$ & $7 \mathrm{~d}$ & $14 \mathrm{~d}$ & & $0 \mathrm{~d}^{\#}$ & $7 \mathrm{~d}$ & & \\
\hline MM-1 & $13.2^{\mathrm{b}}$ & $10.6^{\mathrm{b}}$ & $7.3^{\mathrm{b}}$ & $5.1^{\mathrm{b}}$ & $1.18^{\mathrm{c}}$ & $1.02^{\mathrm{c}}$ & $0.81^{\mathrm{b}}$ & $0.68^{b}$ & $0.76^{\mathrm{a}}$ & $0.70^{\mathrm{b}}$ & $0.57^{\mathrm{b}}$ & $0.48^{\mathrm{ab}}$ \\
\hline MM-2 & $7.2^{\mathrm{c}}$ & $4.7^{\mathrm{d}}$ & $3.3^{\mathrm{c}}$ & $2.3^{\mathrm{c}}$ & $1.08^{\mathrm{d}}$ & $0.82^{\mathrm{f}}$ & $0.60^{\mathrm{c}}$ & $0.46^{\mathrm{c}}$ & $0.74^{\mathrm{a}}$ & $0.66^{\mathrm{c}}$ & $0.50^{\mathrm{de}}$ & $0.39^{\mathrm{de}}$ \\
\hline MM-3 & $5.0^{\mathrm{d}}$ & $3.7^{\mathrm{de}}$ & $2.4^{\mathrm{de}}$ & $1.7^{\mathrm{d}}$ & $1.25^{\mathrm{b}}$ & $1.08^{\mathrm{b}}$ & $0.73^{\mathrm{b}}$ & $0.66^{\mathrm{b}}$ & $0.76^{\mathrm{a}}$ & $0.70^{\mathrm{b}}$ & $0.56^{\mathrm{cd}}$ & $0.46^{\mathrm{bc}}$ \\
\hline MM-4 & $13.3^{\mathrm{b}}$ & $9.44^{\mathrm{c}}$ & $7.0^{\mathrm{b}}$ & $4.8^{\mathrm{b}}$ & $1.09^{\mathrm{d}}$ & $0.91^{\mathrm{d}}$ & $0.61^{\mathrm{c}}$ & $0.52^{\mathrm{b}}$ & $0.76^{\mathrm{a}}$ & $0.69^{b}$ & $0.55^{\mathrm{bc}}$ & $0.42^{\mathrm{cd}}$ \\
\hline MM-5 & $3.2^{\mathrm{e}}$ & $1.85^{\mathrm{f}}$ & $1.2^{\mathrm{f}}$ & $0.78^{\mathrm{f}}$ & $0.85^{\mathrm{e}}$ & $0.60^{\mathrm{g}}$ & $0.46^{\mathrm{d}}$ & $0.35^{\mathrm{d}}$ & $0.70^{\mathrm{a}}$ & $0.60^{d}$ & $0.45^{\mathrm{f}}$ & $0.31^{\mathrm{f}}$ \\
\hline MM-6 & $18.4^{\mathrm{a}}$ & $14.9^{\mathrm{a}}$ & $10.8^{\mathrm{a}}$ & $8.9^{\mathrm{a}}$ & $1.09^{\mathrm{d}}$ & $0.99^{c}$ & $0.76^{\mathrm{b}}$ & $0.70^{\mathrm{b}}$ & $0.77^{\mathrm{a}}$ & $0.74^{\mathrm{a}}$ & $0.61^{\mathrm{a}}$ & $0.51^{\mathrm{a}}$ \\
\hline MM-7 & $5.0^{\mathrm{d}}$ & $4.0^{\mathrm{de}}$ & $2.8^{\mathrm{cd}}$ & $2.2^{\mathrm{c}}$ & $1.55^{\mathrm{a}}$ & $1.34^{\mathrm{a}}$ & $0.98^{\mathrm{a}}$ & $0.85^{\mathrm{a}}$ & $0.75^{\mathrm{a}}$ & $0.70^{\mathrm{b}}$ & $0.57^{\mathrm{b}}$ & $0.49^{\mathrm{ab}}$ \\
\hline MM-8 & $4.3^{\mathrm{de}}$ & $3.0^{\mathrm{e}}$ & $1.9^{\mathrm{e}}$ & $1.3^{\mathrm{e}}$ & $1.15^{\mathrm{c}}$ & $0.87^{\mathrm{e}}$ & $0.64^{\mathrm{c}}$ & $0.49^{c}$ & $0.72^{\mathrm{a}}$ & $0.64^{\mathrm{c}}$ & $0.47^{\text {ef }}$ & $0.36^{\mathrm{e}}$ \\
\hline
\end{tabular}

Biochemical parameters: In general, an increasing trend in $\mathrm{H}_{2} \mathrm{O}_{2}$ concentration in all genotypes was observed with respect to DWD. The highest $\mathrm{H}_{2} \mathrm{O}_{2}$ concentration was measured in genotype MM-5, while it was the lowest in MM-6, especially at 21 DWD. At WW conditions, the lowest MDA content was found in MM-5, which was at par with MM-2, whereas the MDA content was the highest in MM-5 along with MM-8 under severe WD conditions (at 21 DWD). At this WD level, the lowest MDA content was in MM-7 (Table 4). The EL of genotype MM-3, 
MM-7, and MM-6 were minimum and similar under WW conditions, while the maximum EL was observed in MM-2 under WW conditions. The EL was consistently recorded as maximal in MM-5 at each WD level (from 7 to 21 DWD), whereas, it was recorded minimal in MM-6 and MM-7 at 14 and 21 DWD, respectively (Table 4).

The concentration of total $\mathrm{Chl}$ and Car were found to be reduced in all genotypes with the increase of WD from 0 to 7, 14, or 21 DWD. At prolonged WD (21 DWD), the highest total Chl contents was in the genotype MM-6 and Car in MM-6 and MM-7, whereas the total Chl was the lowest in MM-2, MM-8, and MM-4, while genotype
MM-5 showed the lowest Car content under similar conditions (Table 5). Though, similar amount of proline was found in all genotypes at WW conditions, its accumulation increased as the WD stress increased. However, the proline accumulation varied within the genotypes and the content was significantly higher in MM-6 at each WD level in comparison to other genotypes, while the lowest proline content was consistently observed in genotypes MM-2 and MM-5 at each WD level. Statistically, the values of MM-2 and MM-5 were similar to that of MM-7 under 7 DWD, and were also similar to that of MM-8 at 21 DWD (Table 5).

Table 4. Effect of increasing water deficit on hydrogen peroxide $\left(\mathrm{H}_{2} \mathrm{O}_{2}\right)$, MDA, and electrolyte leakage in muskmelon. Data are means \pm SE of three replication. Means followed by the same letter within a column are not significantly different $(P>0.05)$ according to Duncan's multiple range tests; ${ }^{-}$- well-watered plants. 7, 14, and $21 \mathrm{~d}$ represents water-deficit treatment for respective day.

\begin{tabular}{|c|c|c|c|c|c|c|c|c|c|c|c|c|}
\hline \multirow[t]{2}{*}{ Genotype } & \multicolumn{4}{|c|}{$\mathrm{H}_{2} \mathrm{O}_{2}\left[\mu \mathrm{mol} \mathrm{g}{ }^{-1}(\mathrm{FM})\right]$} & \multicolumn{4}{|c|}{ MDA content $\left[\mu \mathrm{mol} \mathrm{g}{ }^{-1}(\mathrm{FM})\right]$} & \multicolumn{4}{|c|}{ Electrolyte leakage [\%] } \\
\hline & $0 \mathrm{~d}^{\#}$ & $7 \mathrm{~d}$ & $14 \mathrm{~d}$ & $21 \mathrm{~d}$ & $0 \mathrm{~d}^{\#}$ & $7 \mathrm{~d}$ & $14 \mathrm{~d}$ & $21 \mathrm{~d}$ & $0 \mathrm{~d}^{\#}$ & $7 \mathrm{~d}$ & $14 \mathrm{~d}$ & $21 \mathrm{~d}$ \\
\hline MM-1 & $15.7^{\mathrm{ab}}$ & $21.3^{\mathrm{bc}}$ & $26.6^{\mathrm{cd}}$ & $52.1^{\mathrm{d}}$ & $1.25^{\mathrm{bcd}}$ & $1.62^{\mathrm{d}}$ & $2.14^{\mathrm{e}}$ & $3.35^{\mathrm{c}}$ & $23.7^{\mathrm{d}}$ & $27.5^{\mathrm{cd}}$ & $38.9^{c}$ & $38.3^{\mathrm{e}}$ \\
\hline MM-2 & $8.28^{\mathrm{d}}$ & $13.5^{\mathrm{d}}$ & $19.1^{\mathrm{ef}}$ & $49.2^{\mathrm{d}}$ & $0.80^{\mathrm{f}}$ & $1.43^{\mathrm{e}}$ & $2.59^{d}$ & $3.24^{\mathrm{c}}$ & $31.5^{\mathrm{a}}$ & $46.8^{\mathrm{a}}$ & $46.1^{\mathrm{b}}$ & $63.0^{\mathrm{b}}$ \\
\hline MM-3 & $12.6^{\mathrm{bcd}}$ & $17.4^{\mathrm{cd}}$ & $22.0^{\text {def }}$ & $55.0^{\mathrm{d}}$ & $1.28^{\mathrm{bc}}$ & $2.02^{\mathrm{b}}$ & $3.28^{\mathrm{b}}$ & $4.25^{\mathrm{b}}$ & $22.0^{\mathrm{e}}$ & $29.4^{\mathrm{c}}$ & $35.3^{\mathrm{d}}$ & $38.7^{\mathrm{e}}$ \\
\hline MM-4 & $20.6^{\mathrm{a}}$ & $28.4^{\mathrm{a}}$ & $36.7^{\mathrm{b}}$ & $86.8^{\mathrm{b}}$ & $1.15^{\mathrm{cd}}$ & $1.77^{\mathrm{cd}}$ & $2.42^{\mathrm{d}}$ & $3.24^{\mathrm{c}}$ & $29.6^{\mathrm{b}}$ & $39.0^{\mathrm{b}}$ & $45.2^{\mathrm{b}}$ & $50.2^{\mathrm{d}}$ \\
\hline MM-5 & $16.0^{\mathrm{abc}}$ & $26.9^{\mathrm{a}}$ & $47.5^{\mathrm{a}}$ & $108.5^{\mathrm{a}}$ & $0.87^{\text {ef }}$ & $1.87^{\mathrm{bc}}$ & $3.41^{\mathrm{b}}$ & $4.87^{\mathrm{a}}$ & $29.4^{\mathrm{b}}$ & $44.7^{\mathrm{a}}$ & $54.0^{\mathrm{a}}$ & $70.1^{\mathrm{a}}$ \\
\hline MM-6 & $10.8^{\mathrm{cd}}$ & $12.4^{\mathrm{d}}$ & $16.1^{\mathrm{f}}$ & $29.7^{\mathrm{e}}$ & $1.90^{\mathrm{a}}$ & $2.26^{\mathrm{a}}$ & $2.92^{\mathrm{c}}$ & $3.28^{\mathrm{c}}$ & $22.6^{\text {de }}$ & $25.1^{\mathrm{d}}$ & $30.7^{\mathrm{e}}$ & $33.4^{\mathrm{f}}$ \\
\hline MM-7 & $17.9^{\mathrm{ab}}$ & $24.0^{\mathrm{ab}}$ & $30.4^{c}$ & $67.8^{\mathrm{c}}$ & $1.05^{\mathrm{de}}$ & $1.38^{\mathrm{e}}$ & $2.01^{\mathrm{e}}$ & $2.72^{\mathrm{d}}$ & $21.7^{\mathrm{e}}$ & $26.8^{\mathrm{cd}}$ & $31.4^{\mathrm{e}}$ & $35.7^{\mathrm{ef}}$ \\
\hline MM-8 & $12.0^{\mathrm{cd}}$ & $17.4^{\mathrm{cd}}$ & $22.8^{\text {de }}$ & $61.7^{\mathrm{c}}$ & $1.41^{\mathrm{b}}$ & $2.37^{\mathrm{a}}$ & $3.95^{\mathrm{a}}$ & $4.71^{\mathrm{a}}$ & $27.6^{\mathrm{c}}$ & $37.3^{\mathrm{b}}$ & $46.4^{\mathrm{b}}$ & $54.1^{\mathrm{c}}$ \\
\hline
\end{tabular}

Table 5. Effect of increasing water deficit on total chlorophyll, carotenoid, and proline content in muskmelon. Data are means \pm SE of three replication. Means followed by the same letter within a column are not significantly different $(P>0.05)$ according to Duncan's multiple range tests; ${ }^{\#}$ - well-watered plants. 7, 14, and $21 \mathrm{~d}$ represents water-deficit treatment for respective day.

\begin{tabular}{|c|c|c|c|c|c|c|c|c|c|c|c|c|}
\hline \multirow[t]{2}{*}{ Genotype } & \multicolumn{4}{|c|}{ Total chlorophyll [mg g $\left.{ }^{-1}(\mathrm{DM})\right]$} & \multicolumn{4}{|c|}{ Carotenoid $\left[\mathrm{mg} \mathrm{g}^{-1}(\mathrm{DM})\right]$} & \multicolumn{4}{|c|}{ Proline $\left[\mu \mathrm{g}\right.$ proline $\left.\mathrm{g}^{-1}(\mathrm{FM})\right]$} \\
\hline & $0 \mathrm{~d}^{\#}$ & $7 \mathrm{~d}$ & $14 \mathrm{~d}$ & $21 \mathrm{~d}$ & $0 \mathrm{~d}^{\#}$ & $7 \mathrm{~d}$ & $14 \mathrm{~d}$ & $21 \mathrm{~d}$ & $0 \mathrm{~d}^{\#}$ & $7 \mathrm{~d}$ & $14 \mathrm{~d}$ & $21 \mathrm{~d}$ \\
\hline MM-1 & $49.2^{\mathrm{b}}$ & $40.3^{\mathrm{bc}}$ & $32.2^{\mathrm{b}}$ & $23.8^{\mathrm{b}}$ & $1.80^{\mathrm{a}}$ & $1.60^{\mathrm{b}}$ & $1.29^{\mathrm{a}}$ & $1.24^{\mathrm{bcd}}$ & $26.7^{\mathrm{a}}$ & $79.4^{\mathrm{b}}$ & $163.7^{\mathrm{b}}$ & $228.0^{\mathrm{b}}$ \\
\hline MM-2 & $56.1^{\mathrm{ab}}$ & $36.0^{\mathrm{cd}}$ & $27.6^{\mathrm{bc}}$ & $14.2^{\mathrm{cd}}$ & $2.01^{\mathrm{a}}$ & $1.54^{\mathrm{bc}}$ & $1.38^{\mathrm{a}}$ & $1.19^{\mathrm{cd}}$ & $24.1^{\mathrm{a}}$ & $39.7^{\mathrm{fe}}$ & $77.0^{\mathrm{f}}$ & $105.4^{\mathrm{f}}$ \\
\hline MM-3 & $63.3^{\mathrm{a}}$ & $46.9^{\mathrm{ab}}$ & $32.9^{\mathrm{b}}$ & $20.0^{\mathrm{b}}$ & $1.83^{\mathrm{a}}$ & $1.48^{\mathrm{bc}}$ & $1.28^{\mathrm{a}}$ & $1.18^{\mathrm{cd}}$ & $25.9^{\mathrm{a}}$ & $49.5^{\mathrm{de}}$ & $124.7^{\mathrm{d}}$ & $147.6^{\mathrm{d}}$ \\
\hline MM-4 & $55.5^{\mathrm{ab}}$ & $42.1^{\mathrm{bc}}$ & $31.6^{\mathrm{b}}$ & $18.5^{\mathrm{bc}}$ & $1.92^{\mathrm{a}}$ & $1.53^{\mathrm{bc}}$ & $1.36^{\mathrm{a}}$ & $1.29^{\mathrm{abc}}$ & $21.9^{\mathrm{a}}$ & $56.0^{\mathrm{cd}}$ & $103.5^{\mathrm{e}}$ & $132.3^{\mathrm{e}}$ \\
\hline MM-5 & $47.8^{\mathrm{b}}$ & $29.4^{\mathrm{d}}$ & $19.3^{\mathrm{d}}$ & $8.7^{\mathrm{d}}$ & $1.93^{\mathrm{a}}$ & $1.41^{\mathrm{c}}$ & $1.19^{\mathrm{a}}$ & $1.02^{\mathrm{e}}$ & $26.7^{\mathrm{a}}$ & $36.9^{f}$ & $77.6^{\mathrm{f}}$ & $101.5^{f}$ \\
\hline MM-6 & $62.3^{\mathrm{a}}$ & $54.0^{\mathrm{a}}$ & $44.9^{\mathrm{a}}$ & $34.9^{\mathrm{a}}$ & $1.98^{\mathrm{a}}$ & $1.78^{\mathrm{a}}$ & $1.49^{\mathrm{a}}$ & $1.39^{\mathrm{a}}$ & $28.0^{\mathrm{a}}$ & $90.3^{\mathrm{a}}$ & $189.2^{\mathrm{a}}$ & $288.2^{\mathrm{a}}$ \\
\hline MM-7 & $51.2^{\mathrm{b}}$ & $42.1^{b c}$ & $31.0^{\mathrm{b}}$ & $23.9^{\mathrm{b}}$ & $1.96^{\mathrm{a}}$ & $1.65^{\mathrm{ab}}$ & $1.45^{\mathrm{a}}$ & $1.33^{\mathrm{ab}}$ & $24.4^{\mathrm{a}}$ & $37.6^{\mathrm{f}}$ & $144.7^{\mathrm{c}}$ & $173.4^{\mathrm{c}}$ \\
\hline MM-8 & $49.2^{\mathrm{b}}$ & $34.2^{\mathrm{cd}}$ & $22.6^{\mathrm{cd}}$ & $13.3^{\mathrm{cd}}$ & $1.91^{\mathrm{a}}$ & $1.42^{\mathrm{c}}$ & $1.24^{\mathrm{a}}$ & $1.15^{\mathrm{d}}$ & $22.2^{\mathrm{a}}$ & $63.9^{\mathrm{c}}$ & $92.8^{\mathrm{e}}$ & $102.8^{f}$ \\
\hline
\end{tabular}

Antioxidant activities: Under WW condtions, the genotype MM-3 showed the maximum SOD activity, while the minimum was found in MM-1 and MM-2. At 7, 14 , and 21 DWD, the maximum SOD activity was recorded for MM-6, whereas minimum was recorded in MM-5, MM-2, and MM-5 (Fig. 1A). At WW conditions, the maximum CAT activity was found in MM-8, though it was at par with MM-5. At 7 DWD, CAT activity was maximal in MM-1, MM-6, and MM-7. However, with the increase in severity of WD (from 14 to 21 DWD), the maximum CAT activity was observed in MM-6. The lowest CAT activity was found in MM-2 at 14 DWD and in MM-2 and MM-5 at 21 DWD (Fig. 1B). The maximum APX activity was recorded in MM-6 at 7, 14, and 21 DWD, while minimum was found in MM-5 at 7 DWD, in MM-2, MM-4, MM-5, MM-8 at 14 DWD, and in MM-5 and MM-8 at 21 DWD (Fig. 1C). Under WW conditions, the GR activity was maximum for MM-3, MM-7, and minimum for MM-2, MM-5, and MM-8, with insignificant difference. At 7 DWD, the GR activity reached maximum in MM-6 and MM-7, while at 14 and 21 DWD, the GR activity was maximal in MM-6. Minimum GR activity was recorded in case of MM-2, MM-5, and MM-8 at 7, 14, and 21 DWD, respectively (Fig. $1 D$ ). The POD activity in 


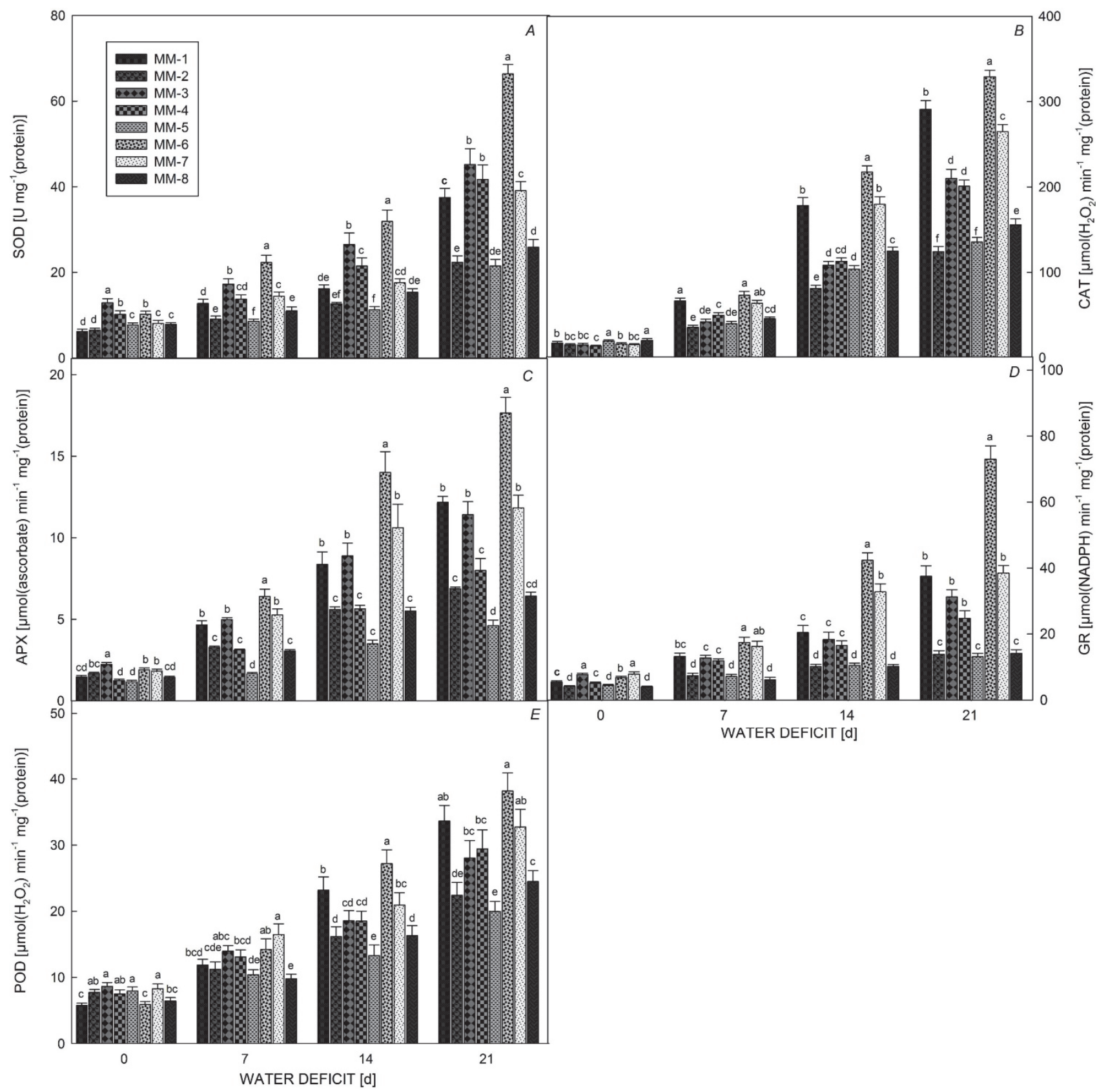

Fig. 1A-E. Effect of increasing water deficit on activities of key antioxidants in muskmelon leaves. $A$ - superoxide dismutase (SOD); $B$ - catalase (CAT); $C$ - ascorbate peroxidase (APX); $D$ - glutathione reductase (GR), $E$ - guaiacol peroxidase (POD). The data are mean of three replicates \pm SE. Those followed by different letters within similar water-stress treatment are significantly different according to Duncan's multiple-range test at $P>0.05$.

MM-3 was maximal, but statistically similar to MM-7, MM-5, and MM-4 at WW conditions. Whereas under WD treatments, and especially at 14 and 21 DWD, the maximum

\section{Discussion}

The response of genotypes to WD may vary with their specific ability to counteract the negative effects of WD. In the present study, WD invariably caused alteration in
POD activity was recorded in MM-6 followed by MM-3 and MM-7, which were statistically similar to each other (Fig. 1E).

some of the plants physiological and biochemical characterstics, such as loss of cell turgor, changes in membrane fluidity and composition, changes in 
compatible organic solute concentrations, and increased activities of antioxidant enzymes. In addition, WD resulted in increased root length. However, these responces varied among the genotypes. The overall responses of plants to stress can be categorized as (1) maintenance of ion homeostasis and osmotic adjustment, and (2) detoxification of harmful elements and metabolism.

A detailed study is required to understand the adaptive mechanisms and responses to WD stress that allow survival of plants under WD conditions. Root system is the main organ responsible for plant water uptake and essential for crop productivity, especially under water stress (Ober and Sharp 2007). Root length represents the morphological trait which better describes the capacity of the root to explore the deeper layer of soil (Ryser 1998). An increase in root length was observed at the progressive WD stages, with the highest root length found in MM-6 and MM-1, especially, under prolonged WD (14 and 21 DWD); this suggests that enhanced root length in these genotypes assist plants to retain maximum water under stress conditions. Matsui and Singh (2003) reported a similar trend of root distribution in various cowpea genotypes grown under WD. They observed a downward shift in root distribution in cowpea plants under WD conditions. Indeed, a deep and prolific root system was found to be associated with enhanced avoidance of drought in chickpea (Serraj et al. 2004) and muskmelon (Huang et al. 2011).

Plants exhibiting better tolerance to WD conditions showed superior water-withholding capacity. Any plant part, which retains more water, exhibits a low ratio of dryto-fresh mass compared to that retaining less water. According to Kravić et al. (2013), a relative increase in the dry-to-fresh mass ratio of roots, shoots, and leaves due to WD could be an indicator of osmotic stress. In the present study, the dry-to-fresh mass ratio of roots, shoots, and leaves increased with duration of WD in all genotypes. The value of dry-to-fresh mass ratio of roots and shoots reached its maximum in MM-6 followed by MM-7, especially at 14 and 21 DWD. Similarly, in muskmelon, the increase in dry mass was observed (Ahmadi-Mirabad et al. 2013). RWC, which measures the maximum amount of water that a tissue can hold, is the most appropriate measure of plant water status in terms of the physiological consequences of cellular WD (Boyer 1968). RWC in all the muskmelon genotypes declined as the DWD progressed. However, the RWC was apparantly higher in MM-6 and MM-7, at 7, 14, and 21 DWD, and hence we propose, as reported by Hessini et al. (2009), the genotypes with higher RWCs (MM-6 and MM-7) can be defined as drought-tolerant, moderate tolerant with moderate RWCs, while the others having lower RWCs (MM-5, MM-4, MM-3, MM-8, and MM-2) as relatively drought-sensitive genotypes. Similar to our findings Ahmadi-Mirabad et al. (2014) also observed a reduction in RWCs in Cucumis melo under deficit irrigation. In tomato, Sánchez-Rodríguez et al. (2010) identified genotypes that were tolerant and sensitive to WD on the basis of RWC.

Drought stress can cause a serious damage to plants at cellular and molecular levels (Gill and Tuteja 2010). Plants facing drought stress show extensive ROS generation that damages their photosynthetic machinery, resulting in a significant decrease in $P_{\mathrm{N}}$. This could be due to abscisic acid-mediated stomatal closure and lesser availability of $\mathrm{CO}_{2}$, resulting in reduced photosynthetic activity (Tahi et al. 2008). In present study, photosynthetic rate declined in all genotypes as the DWD prolonged. The reduction in $P_{\mathrm{N}}$ corresponds with damage to photosynthetic machinery, and with the decline in $g_{\mathrm{s}}$. However, among the genotypes, the maximum $P_{\mathrm{N}}$ was recorded in MM-6 at different WD level (i.e., 7, 14, and 21 DWD). This suggests that the damages caused to photosynthetic machinery due to WD were minimal in MM-6. Under WD, $g_{\mathrm{s}}$ decreased in all genotypes, although the extent of the reduction may vary among genotypes (Cha-um et al. 2010). A reduction in $g_{\mathrm{s}}$ suggests a relationship between WD and stomatal closure. The significantly higher $g_{\text {s }}$ was recorded in MM-7 followed by MM-6 under different WD conditions. Together with $P_{\mathrm{N}}$, the higher $g_{\mathrm{s}}$ in these genotypes suggests their better ability to tolerate $\mathrm{WD}$, since it is widely accepted that increased $g_{\mathrm{s}}$ facilitates $\mathrm{CO}_{2}$ influx into the leaves and the photosynthesis. The efficiency and stability of PSII can be described by the $\mathrm{F}_{\mathrm{v}} / \mathrm{F}_{\mathrm{m}}$ ratio (Ranjbarfordoei et al.2006). Chl fluorescence gives insights into the degree of stress injury to the photosynthetic apparatus. Under $\mathrm{WD}$, restrictions of net $\mathrm{CO}_{2}$ assimilation may promote an imbalance between photochemical activity at PSII, leading to an overexitation and subsequent photoinhibitory damage of PSII reaction centre (Petridis et al. 2012). In response to $\mathrm{WD}$, the photoinhibition was much pronounced in MM-5, especially, under severe WD, while MM-6, MM-1, and MM-7 were able to maintain higher photosynthetic efficiency of PSII, which showed reduced photoinhibition with increasing WD in these genotypes. Petridis et al. (2012) also reported reduction in $\mathrm{F}_{\mathrm{v}} / \mathrm{F}_{\mathrm{m}}$ in Greek olive. Reduction in PSII efficiency was also reported in watermelon plants when treated for different days by drought stress (Mo et al. 2016).

The level of each WD resulted in a decline of the Chl content for each muskmelon genotype. This might be due to damage to the chloroplast structure and a decrease in Chl biosynthesis (Wang et al. 2010). The total Chl content in all the genotypes decreased as the WD progressed. However, the genotype MM-6 could maintain relatively higher Chl content, especially at 14 and 21 DWD, which showed a better ability of MM- 6 to tolerate WD, compared to others. Wang et al. (2010) reported reduction in total Chl content under WD conditions. Such a reduction in the Chl content might be attributed to a decrease in Chl biosynthesis or an increase in Chl degradation. Similarly, reduction also occurred in the Car content due to WD. Such a reduction might be due to Car degradation or a decrease in Car biosynthesis. However, the Car concentration was apparently higher in genotypes MM-6 and 
MM-7 under WD conditions. Role of Car in conferreing tolerance to WD in sesame has been reported. The major role of Car in direct quenching of triplet $\mathrm{Chl}$ prevents the generation of singlet oxygen and protects from oxidative damage (Deng et al. 2003). Wang et al. (2010) reported that the content of Car in the leaves of winter wheat increased under drought stress.

As a result of WD, generation of ROS is enhanced. The presence of $\mathrm{H}_{2} \mathrm{O}_{2}$ is considered indicative of ROS as the half-life of $\mathrm{H}_{2} \mathrm{O}_{2}$ is comparatively longer than that of other ROS, and excess accumulation of $\mathrm{H}_{2} \mathrm{O}_{2}$ in plant cells may lead to oxidative stress (Deeba et al. 2012). Increased $\mathrm{H}_{2} \mathrm{O}_{2}$ production in response to drought stress was reported. In this experiment, the severity of WD induced $\mathrm{H}_{2} \mathrm{O}_{2}$ production in leaves of all genotypes. $\mathrm{H}_{2} \mathrm{O}_{2}$ accumulation in MM-6 was the lowest one, when exposed to WD for longer period, whereas in MM-5, $\mathrm{H}_{2} \mathrm{O}_{2}$ accumulation was the highest one, indicating balanced ROS production in the tolerant as compared to susceptible genotypes (Esfandiari et al. 2008). Enhancement of $\mathrm{H}_{2} \mathrm{O}_{2}$ concentration was earlier reported in watermelon plants under varied drought stress conditions (Mo et al. 2016). MDA is the product of lipid peroxidation and is usually used as a criterion for stress-induced oxidative damage to the membrane. Here, relative to WW plants, stressed plants of all the genotypes showed a gradual increase in MDA concentration as drought intensified, which indicates that MDA concentration was directly related to drought stress. However, the increase in MDA was considerably lower in genotype MM-7 and especially MM-6, which indicates their better tolerance response to WD. Similarly, the increase in MDA concentration under drought conditons was found lower in wild drought-tolerant watermelon plants (Citrullus lanatus var. Citrode) than the cultivated sensitive one (Citrullus lanatus var. lanatus) (Mo et al. 2016). The reduced accumulation of MDA in tomato and muskmelon was also associated with WD tolerance (Kusvuran 2012, Rai et al. 2013). Simova-Stoilova et al. (2010) found more pronounced weakening of membrane integrity and oxidative damage to lipids in the sensitive varieties of wheat plants under WD. Cell membrane stability, assessed by EL method, is widey used to differentiate susceptible and tolerance of a genotype to abiotic stresses; the lower EL is indicative of higher membrane stability and better stress tolerance (Kumar et al. 2015b). The exposure of plants to WD for a longer period proved severe membrane damage, resulting in higher EL and loss of ions, vital factors for proper cell functioning. The present study showed that ion leakage was lower in genotype MM-6 and MM-7, indicating these genotypes as having better membrane stability at WD stress, thus considered as drought-tolerant genotypes. Previously, Valentovič et al. (2006) reported a susceptible maize cultivar that showed a more pronounced increase in EL than that of a tolerant one.

It is well known that osmotic stresses induce oxidative damage, which can be reduced by the activation of antioxidant enzymes and the biosynthesis of osmolytes acting as
ROS scavengers. Stress-induced variation of antioxidants is dependent on the severity and duration of the treatment, and also the species and age of the plant (Shao et al. 2007). SOD is an ubiquitous enzyme in plants that plays a major role in the defense mechanism against generated ROS through catalyzing the disproportionation of superoxide radicals to molecular oxygen and $\mathrm{H}_{2} \mathrm{O}_{2}$. In fact, SOD reduces the risk of hydroxyl radical formation from superoxide via the metal-catalyzed Haber-Weiss-type reaction by removing the superoxide (Arora et al. 2002). Enhanced SOD activity has been reported in white clover (Wang and Li 2008) and cabbage (Singh et al. 2010) under drought stress. In present experiment, WD also led to relatively higher activity of SOD in all genotypes, where the highest SOD activity was observed in genotypes showing a drought-tolerant response (e.g., MM-6) relative to drought-sensitive genotypes (e.g., MM-2 and MM-5). $\mathrm{H}_{2} \mathrm{O}_{2}$ produced as a result of SOD activity and other reactions is destroyed by CAT in a further reaction (Foyer et al. 1994). CAT is tetrameric heme containing enzyme that is abundant in the glyoxysomes of lipid storing tissues. In this study, enhanced CAT activity observed at each WD in all genotypes, but the highest CAT activity was recorded in MM-6 compared to other genotypes, suggesting better $\mathrm{H}_{2} \mathrm{O}_{2}$-scavenging ability of tolerant genotypes. Rai et al. (2013) also observed that better performance of tomato under drought stress is accompanied by an increase in CAT activity. APX plays a key role in decreasing $\mathrm{H}_{2} \mathrm{O}_{2}$ accumulation and eliminating MDA. Higher APX activity was observed in drought-exposed plants, with MM-6 showing the highest APX activity analyzed at different DWD. Increased APX activity has been reported in a drought-stressed soybean genotype (Zhang et al. 2006). It is assumed that the increased activities of the enzymes associated with the ascorbate/glutathione pathway, especially APX, confer general resistance to environmental stresses (Carvalho 2008). High GR activity maintains the pool of glutathione in the reduced state. Increased GR activity as WD progresses ensures availability of $\mathrm{NADP}^{+}$, which accepts electrons from the photosynthetic electron-transport chain (Sofo et al. 2005). Ratnayaka et al. (2003) reported enhanced GR activity in cotton during drought stress. In the present study, muskmelon genotypes exposed to WD conditions showed significantly higher GR activity, and the highest GR activity was observed in MM-6. Under WD conditions, induction of POD activity compensates for CAT and APX activities. PODs degrade indole-3-acetic acid and participate in the biosynthesis of lignin; POD also consumes $\mathrm{H}_{2} \mathrm{O}_{2}$. Higher POD activity has been reported in droughttolerant genotypes of common bean, sunflower, and sorghum (McKersie et al. 1999). Here, POD activity increased with duration of the WD and genotype MM-6 and MM-7 showed significantly higher POD activity. Whereas, the minimum POD activity was obvious in susceptible genotype MM-5 at 21 DWD. 
A common response of plants to WD is accumulation of free proline. Proline acts as a mediator for osmotic adjustment and eliminates free radicals, and it is also an important component of cell-wall proteins. Proline accumulation is well recognized in drought-tolerant genotypes as compared to susceptible ones under WD conditions (Ashraf and Foolad 2007). Similarly, we observed enhanced accumulation of proline under elevated WD, with the highest concentration found in the genotype MM-6, at each WD level. This indicates that free proline also contributes to better protection against oxidative damage in this muskmelon genotype (Ansari et al. 2016).

Conclusion: The general response of muskmelon plants to WD included the increase in root length and decrease in RWC, photosynthetic rate, stomatal conductance, maximum quantum-use efficiency of PSII $\left(\mathrm{F}_{\mathrm{v}} / \mathrm{F}_{\mathrm{m}}\right)$, and photosynthetic pigments. However, the extent of these changes differed between the genotypes with respect to degree of WD. The negative effects of WD were less pronounced in genotypes MM-6, MM-7, and MM-1, which showed a drought-tolerance response, whereas the other genotypes

\section{References}

Adibah M.S.R., Ainuddin AN.: Epiphytic plants responses to light and water stress. - Asian J. Plant Sci. 10: 97-107, 2011.

Ahmadi-Mirabad A., Lotfi M., Roozban M.R.: Growth, yield, yield components and water-use efficiency in irrigated cantaloupes under full and deficit irrigation. - Electron. J. Biol. 10: 79-84, 2014.

Ahmadi-Mirabad A., Lotfi M., Roozban M.R.: Impact of waterdeficit stress on growth, yield and sugar content of cantaloupe (Cucumis melo L.). - Int. J. Agric. Crop Sci. 5: 2778-2782, 2013.

Ansari W.A., Atri M., Singh B. et al.: Changes in antioxidant enzyme activities and gene expression in two muskmelon genotypes under progressive water stress. - Biol. Plantarum 61: 333-341, 2017.

Arora A., Sairam R.K., Srivastava G.C.: Oxidative stress and antioxidative system in plants. - Curr. Sci. 82: 1227-1238, 2002.

Ashraf M., Foolad M.R.: Roles of glycine betaine and proline in improving plant abiotic stress resistance. - Environ. Exp. Bot. 59: 206-216, 2007.

Bates L.S., Walden R.P., Teare I.D.: Rapid determination of free proline for water stress studies. - Plant Soil 39: 205-207, 1973.

Boyer J.S.: Measurement of the water status of plants. - Annu. Rev. Plant Physiol. 9: 351-363, 1968.

Cabello M.J., Castellanos M.T., Romojaro F. et al.: Yield and quality of melon grown under different irrigation and nitrogen rates. - Agr. Water Manage. 96: 866-874, 2009.

Carvalho M.H.C.: Drought stress and reactive oxygen species. Plant Signal Behav. 3: 156-165, 2008.

Cha-um S., Nhung N.T.H., Kirdmanee C.: Effect of mannitol and salt-induced iso-osmotic stress on proline accumulation, photosynthetic abilities and growth characters of rice cultivars (Oryza sativa L. spp. indica). - Pak. J. Bot. 42: 927-941, 2010.

Cha-um S., Samphumphuang T., Kirdmanee C.: Glycinebetaine alleviates water deficit stress in indica rice using proline were susceptible. An indicator of membrane damage (EL) increased under WD conditions, but tolerant genotypes exhibited a lesser enhancement of this parameter. The level of oxidative stress, as evidenced by increased EL and lipid peroxidation, associated with higher $\mathrm{H}_{2} \mathrm{O}_{2}$ production, was lower in genotypes MM-6 and MM-7 compared to the other genotypes, especially MM-5 and MM-2. Similarly, relatively higher activities of antioxidant enzymes (SOD, CAT, APX, GPX, and GR) and concentrations of metabolites, such as proline, indicated in MM-6, MM-7 and MM1 a tolerant response that can more efficiently restrain oxidative stress.

Thus, it was apparent from the present investigation that drought tolerance in muskmelon is genotype-specific and can determined by the combined effects of various physiological, biochemical, and growth-related parameters. These factors are indicators at the cellular level and may serve as in vitro selection criteria for drought tolerance in muskmelon. Overall, MM- 6 can be considered the most drought-tolerant genotype, followed by MM-7, and these lines may be useful in future breeding programs as potential donors of drought-tolerance genes.

accumulation, photosynthetic efficiencies, growth performances and yield attributes. - Aust. J. Crop Sci. 7: 213-218, 2013. Cha-um S., Supaibulwatana K., Kirdmanee C.: Glycinebetaine accumulation, physiological characterizations and growth efficiency in salt tolerant and salt sensitive lines of indica rice (Oryza sativa L. spp. indica) response to salt stress. - J. Agron. Crop. Sci. 193: 157-166, 2007.

Chaves M.M., Pereira J.S., Maroco J. et al.: How plants cope with water stress in the field? Photosynthesis and growth. Ann. Bot.-London 89: 907-916, 2002.

Colla G., Rouphael Y., Jawad R. et al.: The effectiveness of grafting to improve $\mathrm{NaCl}$ and $\mathrm{CaCl}_{2}$ tolerance in cucumber. Sci. Hortic.-Amsterdam 164: 380-391, 2013.

Deeba F., Pandey A.K.., Ranjan S. et al.: Physiological and proteomic responses of cotton (Gossypium herbaceum L.) to drought stress. - Plant Physiol. Bioch. 53: 6-18, 2012.

Deng X., Hu Z.A., Wang H.X. et al.: A comparison of photosynthetic apparatus of the detached leaves of the resurrection plant Boea hygrometrica with its non-tolerant relative Chirita heterotricha in response to dehydration and rehydration. Plant Sci. 165: 851-861, 2003.

Dhillon N.P., Monforte A.J., Pitrat M. et al.: Melon landraces of India: contributions and importance. - Plant Breed. Rev. 35: 85-150, 2011.

Esfandiari E., Shakiba M.R., Mahboob S.A. et al.: The effect of water stress on the antioxidant content, protective enzyme activities, proline content and lipid peroxidation in wheat seedling. - Pak. J. Biol. Sci. 11: 1916-1922, 2008.

Feng X.H., Wu D.K.: Planting cucurbits in gravel mulched land. - China Cucurb. Veget. 1: 57-58, 2007.

Fleury D., Jefferies S., Kuchel H. et al.: Genetic and genomic tools to improve drought tolerance in wheat. - J. Exp. Bot. 61: 3211-3222, 2010.

Foyer C.H., Descourvières P., Kunert K.J.: Protection against oxygen radicals: an important defense mechanism studied in 
transgenic plants. - Plant Cell Environ. 17: 507-523, 1994.

Gill S.S., Tuteja A.N.: Reactive oxygen species and antioxidant machinery in abiotic stress tolerance in crop plants. - Plant Physiol. Bioch. 48: 909-930, 2010.

Heath R.L., Packer L.: Photoperoxidation in isolated chloroplasts: I. Kinetics and stechiometry of fatty acid peroxidation. - Arch. Biochem. Biophys. 125: 189-198, 1968.

Hessini K., Martinez J.P., Gandour M. et al.: Effect of water stress on growth, osmotic adjustment, cell wall elasticity and water-use efficiency in Spartina alterniflora. - Environ. Exp. Bot. 67: 312-319, 2009.

Huang Z., Zou Z., He C. et al.: Physiological and photosynthetic responses of melon (Cucumis melo L.) seedlings to three Glomus species under water deficit. - Plant Soil 339: 391-399, 2011.

Ibrahim E.A.: Variability, heritability and genetic advance in Egyptian sweet melon (Cucumis melo var. Aegyptiacus L.) under water stress condition. - Int. J. Plant Breed. Genet. 6: 238-244, 2012.

Jaleel C.A., Gopi R., Panneerselvam R.: Growth and photosynthetic pigments responses of two varieties of Catharanthus roseus to triadimefon treatment. - C. R. Biol. 331: 272-277, 2008.

Jana S., Choudhuri M.A.: Glycolate metabolism of three submerged aquatic angiosperm during aging. - Aquat. Bot. 12: 345-354, 1981.

Kausar A., Ashraf M.Y., Ali I. et al.: Evaluation of sorghum varieties/lines for salt tolerance using physiological indices as screening tool. - Pak. J. Bot. 44: 47-52, 2012.

Khare N., Goyary D., Singh N.K et al.: Transgenic tomato cv. Pusa Uphar expressing a bacterial mannitol-1-phosphate dehydrogenase gene confers abiotic stress tolerance. - Plant Cell Tiss. Org. Cult. 103: 267-277, 2010.

Kravić N., Marković K., Anđelković V. et al.: Growth, proline accumulation and peroxidase activity in maize seedlings under osmotic stress. - Acta Physiol. Plant. 35: 233-239, 2013.

Kumar P., Lucini L., Rouphael Y. et al.: Insight into the role of grafting and arbuscular mycorrhiza on cadmium stress tolerance in tomato. - Front. Plant Sci. 6: 477, 2015a.

Kumar P., Rouphael Y., Cardarelli M. et al.: Effect of nickel and grafting combination on yield, fruit quality, antioxidative enzyme activities, lipid peroxidation, and mineral composition of tomato. - J. Plant Nutr. Soil Sci. 178: 848-860, 2015 b.

Kusvuran S.: Effects of drought and salt stresses on growth, stomatal conductance, leaf water and osmotic potentials of melon genotypes (Cucumis melo L.). - Afr. J. Agr. Research 7: 775-781, 2012.

Lawlor D.W.: Limitation to photosynthesis in water-stressed leaves: Stomatal metabolism and the role of ATP. - Ann. Bot.London 89: 871-885, 2002.

Lee B.R., Jin Y.L., Avice J.C. et al.: Increased proline loading to phloem and its effects on nitrogen uptake and assimilation in water-stressed white clover (Trifolium repens). - New Phytol. 182: 654-663, 2009.

Lichtenthaler H.K., Buschmann C.: Chlorophylls and carotenoids: Measurement and characterization by UV-VIS spectroscopy. - In: Wrolstad R.E., Acree T.E., An H. et al. (ed.): Current Protocols in Food Analytical Chemistry. Pp. F4.3.1-F4.3.8. John Wiley \& Sons, New York 2001.

Lowry O.H, Rosebrough J.J, Farr A.L. et al.: Estimation of protein with the folin-phenol reagent. - J. Biol. Chem. 193: 265-275, 1951.

Matsui T., Singh B.B.: Root characteristics in cowpea related to drought tolerance at the seedling stage. - Exp. Agr. 39: 29-38, 2003.

Maxwell K., Johnson G.N.: Chlorophyll fluorescence - a practical guide. - J. Exp. Bot. 51: 659-668 , 2000.

McKersie B.D., Bowley S.R., Jones K.S.: Winter survival of transgenic alfalfa over expressing superoxide dismutase. Plant Physiol. 119: 839-848, 1999.

Mo Y., Yang R., Liu L. et al.: Growth, photosynthesis and adaptive responses of wild and domesticated watermelon genotypes to drought stress and subsequent re-watering. - Plant Growth Regul. 79: 229-241, 2016.

Nakano Y., Asada K.: Hydrogen peroxide is scavenged by ascorbate specific peroxides in spinach chloroplast. - Plant Cell Physiol. 22: 867-880, 1981.

Ober E.S, Sharp R.E.: Regulation of root growth responses to water deficit. - In: Jenks M.A., Hasegawa P.M., Jain S.M. (ed.): Advances in Molecular Breeding toward Drought and Salt Tolerant Crops. Pp. 33-53. Springer, Dortrecht 2007.

Pandey S., Ansari W.A., Atri N. et al:: Standardization of screening technique and evaluation of muskmelon genotypes for drought tolerance. - Plant Genet. Resour.-C. DOI:10.1017/S1479262116000253, 2016.

Pandey S., Ansari W.A., Jha A. et al.: Evaluation of melons and indigenous Cucumis spp. genotypes for drought tolerance. Acta Hortic. 979: 335-339, 2013.

Pandey S., Rai M., Prasanna H.C. et al.: 'Kashi Madhu': a new muskmelon cultivar with high total soluble solids. HortScience 43: 245-246, 2008.

Penella C., Nebauer S.G., Bautista A.S. et al.: Rootstock alleviates PEG-induced water stress in grafted pepper seedlings: physiological responses. - J. Plant Physiol. 171: 842-851, 2014

Petridis A., Therios I., Samouris G. et al.: Effect of water deficit on leaf phenolic composition, gas exchange, oxidative damage and antioxidant activity of four Greek olive (Olea europaea L.) cultivars. - Plant Physiol. Bioch. 60: 1-11, 2012.

Rai A.C, Singh M., Shah K.: Effect of water withdrawal on formation of free radical, proline accumulation and activities of antioxidant enzymes in ZAT12- transformed transgenic tomato plants. - Plant Physiol. Bioch. 61: 108-114, 2012.

Rai G.K., Rai N.P., Rathaur S.: Expression of rd29A::AtDREB1A/CBF3 in tomato alleviates droughtinduced oxidative stress by regulating key enzymatic and nonenzymatic antioxidants. - Plant Physiol. Bioch. 69: 90-100, 2013.

Ranjbarfordoei A., Samson R., Damme P.V.: Chlorophyll fluorescence performance of sweet almond [Prunus dulcis (Miller) D. Webb] in response to salinity stress induced by NaCl. - Photosynthetica 44: 513-522, 2006.

Ratnayaka H., Molin W.T., Sterling T.M.: Physiological and antioxidant responses of cotton and spurred anoda under interference and mild drought. - J. Exp. Bot. 54: 2293-2305, 2003.

Ryser P.: Intra- and interspecific variation in root length, root turnover and the underlying parameters. - In: Lambers $\mathrm{H}$, Poorter H, van Vuuren M.M.I. (ed.): Inherent Variation in Plant Growth. Physiological Mechanism and Ecological Consequences. Pp. 441-465. Backhuys Publishers, Leiden 1998.

Sánchez-Rodríguez E., Rubio-Wilhelmi M.M., Cervilla L.M. et al:: Genotypic differences in some physiological parameters symptomatic for oxidative stress under moderate drought in tomato plants. - Plant Sci. 178: 30-40, 2010.

Serraj R., Krishnamurthy L., Kashiwagi J. et al.: Variation in root 
traits of chickpea (Cicer arietinum L.) grown under terminal drought. - Field Crop. Res. 88: 115-127, 2004.

Shah K., Kumar R.G., Verma S. et al.: Effect of cadmium on lipid peroxidation, superoxide anion generation and activities of antioxidant enzymes in growing rice seedlings. - Plant Sci. 161: 1135-1144, 2001.

Shao H.B., Jiang S.Y., Li F.M. et al.: Some advances in plant stress physiology and their implications in the systems biology era. - Colloid. Surface B 54: 33-36, 2007.

Simova-Stoilova L., Vaseva I., Grigorova B. et al.: Proteolytic activity and cysteine protease expression in wheat leaves under severe soil drought and recovery. - Plant. Physiol. Bioch. 48: 200-206, 2010.

Singh B.K., Sharma S.R., Singh B.: Antioxidant enzymes in cabbage: variability and inheritance of superoxide dismutase, peroxidase and catalase. - Sci. Hortic.-Amsterdam 124: 9-13, 2010.

Sofo A., Tuzio A.C., Dichio B. et al.: Influence of water deficit and rewatering on the components of the ascorbate glutathione cycle in four interspecific Prunus hybrids. - Plant Sci. 169:
403-412, 2005.

Tahi H., Wahbi S., Modafar C.E. et al.: Changes in antioxidant activities and phenol content in tomato plants subjected to partial root drying and regulated deficit irrigation. - Plant Biosyst. 142: 550-562, 2008.

Valentovič P., Luxová M., Kolarovič L. et al.: Effect of osmotic stress on compatible solutes content, membrane stability and water relations in two maize cultivars. - Plant Soil Environ. 52: 186-191, 2006.

Wang C.Q., Li R.C.: Enhancement of superoxide dismutase activity in the leaves of white clover (Trifolium repens L.) in response to polyethylene glycol-induced water stress. - Acta Physiol. Plant. 30: 841-847, 2008.

Wang H., Zhang L., Ma J. et al.: Effects of water stress on reactive oxygen species generation and protection system in rice during grain-filling stage. - Agr. Sci. China 9: 633-641, 2010.

Zhang J., Jia W., Yang J., Ismail A.M.: Role of ABA in integrating plant responses to drought and salt stresses. - Field Crops Res. 97: 111-119, 2006. 